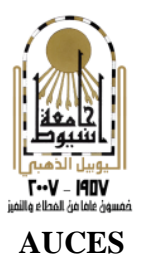

\title{
INFESTATION PREDISPOSITION AND RELATIVE SUSCEPTIBILITY OF CERTAIN EDIBLE FRUIT CROPS TO THE NATIVE AND INVADING FRUIT FLIES (DIPTERA: TEPHRITIDAE) IN THE NEW VALLEY OASES, EGYPT
}

\author{
Mohamed A. Amro* and Farouk A. Abdel-Galil** \\ *Plant Protection Research Institute, Agricultural Research Center, Dokki, Giza, Egypt \\ Email Address: a7med_3mr@yahoo.com. \\ **:Plant Protection Department, Faculty of Agriculture, Assiut University, Assiut, Egypt \\ Email Address: faagalil@hotmail.com
}

\begin{abstract}
:
Infestation predisposition and relative susceptibility of the most common edible fruits cultivated in the New Valley Oases against Ceratitis capitata (Wiedemann) and Bactrocera zonata (Saunders) have been determined. Because high percentage of pupae was unable to produce adults, the percentage of the emerged adult flies was used to express the real ability of infestation. At Kharga province Naring ranked the first in terms of the infestation predisposition by $\mathbf{5 7 . 0 4 \%}$ real infestation. The rest host fruits exhibited variable infestation predisposition lasted by Apple (11.25\%). Quitely difference in the infestation predisposition appeared in Dakhla Oases. In Moot province, Guava ranked the first by $45.00 \%$. However, in Bodkholo province Apricot ranked the first by $62.22 \%$. Variations among the rest of the tested host plants were determined and discussed. In general, data showed that $B$. zonata ranked the first in respect to the number and the percentage of the emerged adults than $C$. capitata.

Classification of the tested host plants to their susceptibility degrees to fruit flies indicated that Naring ranked the first in terms of susceptibility to $C$. capitata and B. zonata complex and appeared as highly susceptible (HS) host plant. It followed by Guava and Orange which appeared as susceptible (S) host plants. Inversely, Mandarin and Apple showed some sort of resistance and appeared as relatively resistant (RR) host plants. However, Mango appeared as moderately resistant (MR), because it harbored the lowest numbers of emerged adult flies. On the other hand, Fig could be considered as a resistant (R) host plant, because no adult flies emerged from pupae collected from its fruits. Host plants free from infestation were hoped but not found.
\end{abstract}




\section{INTRODUCTION:}

The Mediterranean fruit fly or Medfly, Ceratitis capitata (Wiedemann), is one of the world's most destructive fruit pests. The species originates in the Mediterranean region of Europe and North Africa. This pest attacks more than 260 different fruits, flowers, vegetables and nuts. Thin-skinned, ripe, succulent fruits are preferred. Host preferences vary in different regions. An extensive host list is provided by Weems (1981).

The peach fly, Bactrocera zonata (Saunders) originates in South and South-East Asia, where it attacks many fruit species (more than 50 host plants), including guavas, mangoes, peach, apricots, figs and citrus (White and ElsonHarris, 1992). The pest has spread to other parts of the world, in particular to several countries in the Near East and to Egypt. In 1924, B. zonata was declared present in Egypt. In 1998, $B$. zonata was identified for the first time on infested guavas collected in Agamy and Sabahia, near Alexandria. In 1999, the first traps were set up and showed high capture rates in Alexandria and Cairo. In October 2000, B. zonata was detected in North Sinai. At present, it is considered that $B$. zonata is present and widespread in Egypt (Internet cite/ www.eppo.org). Abdel-Galil (2007) studied the distribution and infestation patterns of $B$. zonata in the New Valley Oases. He stated that larval feeding damage in fruits caused by this pest is the most damaging. Mature attacked fruits may develop a water soaked appearance. Young fruits become distorted and usually drop. The larval tunnels provide entry points for bacteria and fungi that cause the fruit rot.

Therefore, the aim of the present work which submitted by the Academy of Scientific Research and Technology, Cairo, Egypt, as a part of ongoing project entitled "Study on biological means for controlling the Mediterranean fruit fly Ceratitis capitata (Wiedemann) in New Valley Governorate", is to provide information on the infestation predisposition of the dominant edible fruits cultivated in the New Valley Oases by $C$. capitata and $B$. zonata and to determine the relative susceptibility of these host plants to these tephritid flies.

\section{MATERIALS AND METHODS:}

Nine mixed orchards were selected in three provinces (Khargha, Moot and Bodkholo) in the New Valley Oases, to determine the infestation predisposition and the relative susceptibility of the common host plants to $C$. capitata and $B$. zonata. Fruits chosen were: Guava, Orange, Mandarin, Naring, Mango, Apple, Apricot, Fig and Sabot. Ripening and newly fallen host fruits were randomly collected from and under host trees. Samples were transported to the laboratory, where each sample was placed in a plastic tray over sand in a screened box (Fig. 1) and the emerged larvae or pupae were collected one or two times per week, and the sand was renewed and the fruit liquids were eliminated. The pupae of $C$. capitata and $B$. zonata as a complex were placed in vials on sterile sand until adult emergence under the laboratory conditions, $28 \pm 2^{\circ} \mathrm{C}$ and $60 \pm 5 \%$ R.H.

\section{Infestation predisposition:}

Infestation predisposition was based on the produced number of pupae (dead pupae plus the number of emerged flies). All infestation data shown are in terms of number of pupae produced per each collected fruit. Consequently, the real infestation is dependent on the percentage of the emerged adult flies. Similar technique was established by Eskafi and Kolbe (1990). 


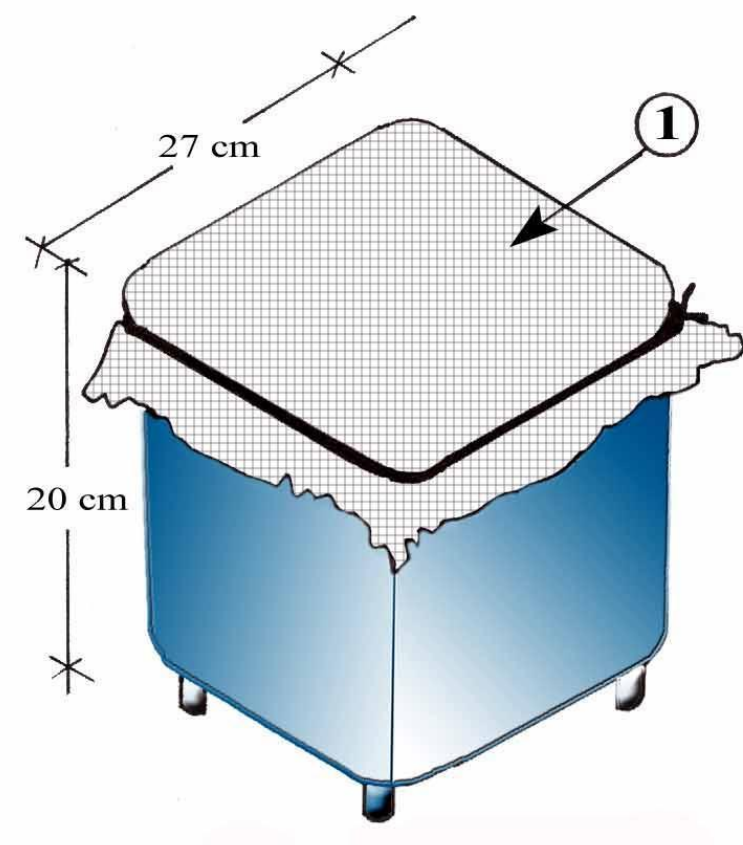

(7)
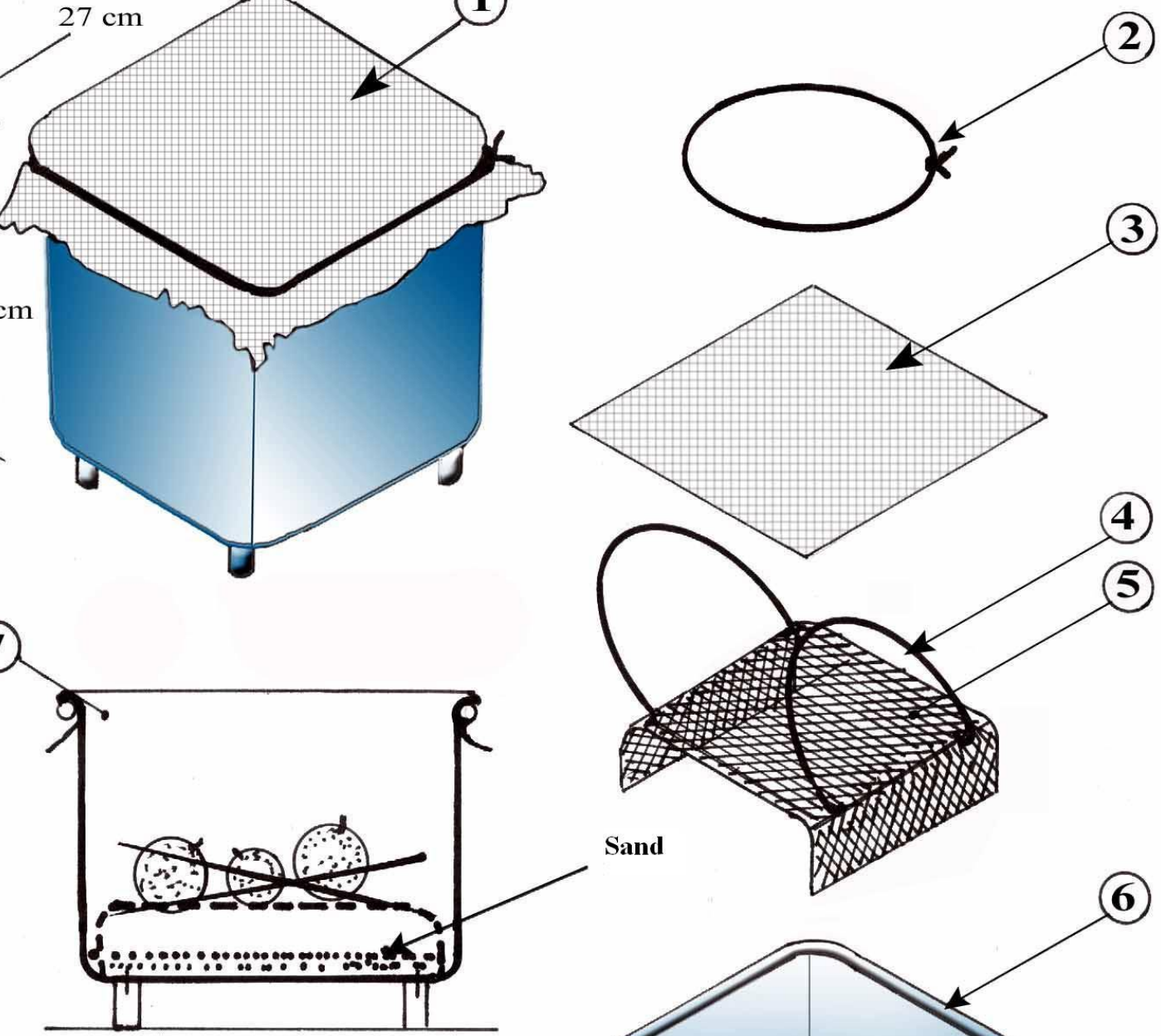

2
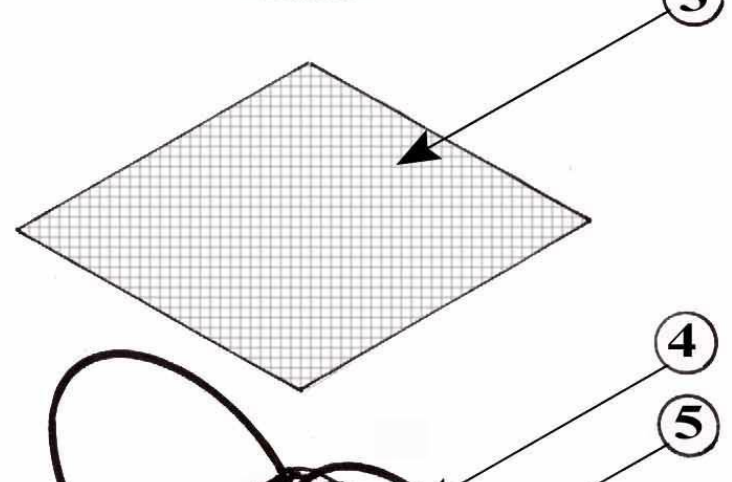

1- General View

2- Rubber Band

3- White Muslin

4- Hanging Wire

5- Wire Net

6- Plastic Container

7-Longitudinal Section

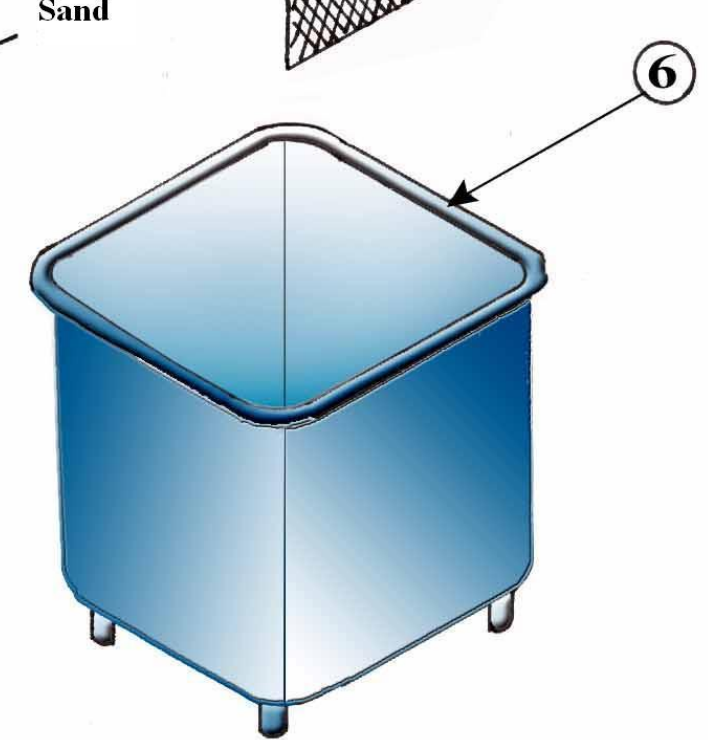

Figure (1): Isolation unit of fruit flies pupae collected from ripening and fallen fruits 


\section{Relative susceptibility:}

Classification of the susceptibility degrees of the tested host plants to fruit flies infestation could depend on the umber of the emerged adult flies per fruit as reported by Chiang and Talekar (1980), Nosser (1996) and Amro (1999) with few modifications. General mean number (MN), of emerged adult flies/fruit was considered as the standard of classification. Range of change in susceptibility (RC) within a given host plant is equal: Maximum mean number - Minimum mean number. Unit change in host plants (UC) is the amount of change from one degree of susceptibility to the proceeding or the preceding degree whereas, $\mathrm{UC}=\mathrm{RC} / 4$. So, the tested host plants could be classified into the following categories. The host plants that had emerged adult flies more than (MN+UC) were considered highly susceptible (HS); ranging from $\mathrm{MN}$ to $(\mathrm{MN}+\mathrm{UC})$, susceptible(S); less than MN to (MN-UC), relatively resistant $(\mathrm{RR})$; ranging from $<(\mathrm{MN}-$ UC) to (Mn-2UC), moderately resistant (MR) and less than (MN-2UC) were considered resistant $(R)$. Data obtained were statistically analyzed by using F-test. The means were compared according to Duncan's multiple range tests (Snedecor and Cochran, 1971).

\section{RESULTS AND DISCUSSION:}

Infestation predisposition of $C$. capitata and $B$. zonata:

Nine species of tephritid host plants, the amount of fruits collected from Kharga, Moot and Bodkholo provinces at Dakhla Oases, in addition to another correlated data, are listed in Tables (1-3). Mean numbers of pupae per fruit showed considerable variations among host species. At Kharga Oases, results presented in (Table1) indicated that the tested host plants harbored mean numbers of pupae ranging from 4.78 to 11.25 pupae/fruit. Infestation predisposition arranged descendingly according to the number of pupae/fruit as follows: Naring by 11.25> Mandarin by $9.85>$ Orange by 7.12>Apple by 6.67>Mango by 5.02>Guava by 4.78 pupae/fruit. The percentage of the emerged adult flies expressed about the real infestation, whereas high percentage of pupae was unable to produce adults. The highest percentage of emerged adults was recorded on Naring by $57.04 \%$, and the lowest was recorded on Apple by $11.25 \%$. The rest host plants exhibited variance infestation predispositions. Antibiosis phenomenon as one of the host plant resistance factors could be responsible for these variations. In this approach, the relation between the number of mature fruits available on trees and C. capitata infestation was studied by Eskafi and Kolbe (1990). On the other hand, Tsitsipis (1992) reported that host fruit had an important role in the development of fruit flies.

Data presented in Table (2) indicated that the highest numbers of pupae collected from Moot province occurred on Guava and Orange by 7.55 and 7.40 pupae/fruit, respectively. It followed by Naring, Mandarin, Apple and Mango by 4.94, 4.50, 4.37 and 2.70 pupae/fruit, respectively. The lowest number was recorded on Fig by 0.23 pupae/fruit. On the other hand, the host fruits were arranged descendingly according to the percentages of the emerged adult flies as follows: Guava by 45.00> Apple by 41.36> Mandarin by 40.89>Naring by 38.10> Orange by 24.82> Mango by $1.20 \%$. No adult flies were emerged from pupae collected from Fig fruits. 
Table (1): Infestation predisposition of host plants to Bactrocera zontata and Ceratitis capitata at Kharga Oases during 2004-2006 seasons

\begin{tabular}{|c|c|c|c|c|c|c|c|c|c|c|c|c|}
\hline \multirow{3}{*}{$\begin{array}{c}\text { Host } \\
\text { plants }\end{array}$} & \multirow{3}{*}{$\begin{array}{c}\text { No. } \\
\text { of } \\
\text { samples }\end{array}$} & \multirow{3}{*}{$\begin{array}{c}\text { No. } \\
\text { of } \\
\text { fruits }\end{array}$} & \multirow{3}{*}{$\begin{array}{c}\text { No. } \\
\text { of } \\
\text { pupae }\end{array}$} & \multirow{3}{*}{$\begin{array}{c}\text { No. of } \\
\text { pupae/ } \\
\text { fruit }\end{array}$} & \multicolumn{2}{|c|}{ Dead pupae } & \multicolumn{6}{|c|}{ Emerged adults } \\
\hline & & & & & \multirow{2}{*}{ No. } & \multirow{2}{*}{$\%$} & \multirow{2}{*}{ No. } & \multirow{2}{*}{$\%$} & \multicolumn{2}{|c|}{ B. zonata } & \multicolumn{2}{|c|}{ C. capitata } \\
\hline & & & & & & & & & No. & $\%$ & No. & $\%$ \\
\hline \multirow{3}{*}{ Guava } & $2004(4)$ & 111 & 282 & 2.50 & 243 & 86.17 & 39 & 13.83 & 39 & 100.00 & 0.00 & 0.00 \\
\hline & $2005(6)$ & 358 & 1555 & 4.34 & 1494 & 96.08 & 61 & 3.92 & 61 & 100.00 & 0.00 & 0.00 \\
\hline & $2006(2)$ & 56 & 673 & 12.02 & 221 & 32.83 & 452 & 67.71 & 452 & 100.00 & 0.00 & 0.00 \\
\hline \multirow{3}{*}{ Orange } & $2004(2)$ & 19 & 177 & 9.13 & 85 & 48.02 & 92 & 51.98 & 92 & 100.00 & 0.00 & 0.00 \\
\hline & $2005(2)$ & 14 & 58 & 4.14 & 30 & 51.72 & 28 & 48.28 & 28 & 100.00 & 0.00 & 0.00 \\
\hline & Total (4) & 33 & 235 & 7.12 & 115 & 48.94 & 120 & 51.06 & 120 & 100.00 & 0.00 & 0.00 \\
\hline Mandarin & Total (15) & 179 & 1764 & 9.85 & 1256 & 71.20 & 508 & 28.80 & 508 & 100.00 & 0.00 & 0.00 \\
\hline Naring & 2004 (2) & 12 & 135 & 11.25 & 58 & 42.96 & 77 & 57.04 & 68 & 88.31 & 9.00 & 11.69 \\
\hline \multirow{3}{*}{ Mango } & 2004 (2) & 7 & 47 & 6.71 & 29 & 61.70 & 18 & 38.30 & 18 & 100.00 & 0.00 & 0.00 \\
\hline & 2005 (4) & 110 & 540 & 4.91 & 350 & 64.81 & 190 & 35.19 & 190 & 100.00 & 0.00 & 0.00 \\
\hline & Total (6) & 117 & 587 & 5.02 & 379 & 64.57 & 208 & 35.43 & 208 & 100.00 & 0.00 & 0.00 \\
\hline Apple & 2005 (2) & 60 & 400 & 6.67 & 355 & 88.75 & 45 & 11.25 & 45 & 100.00 & 0.00 & 0.00 \\
\hline
\end{tabular}

Table (2): Infestation predisposition of host plants to Bactrocera zontata and Ceratitis capitata at (Moot) Dakhla Oases during 2004-2005 seasons

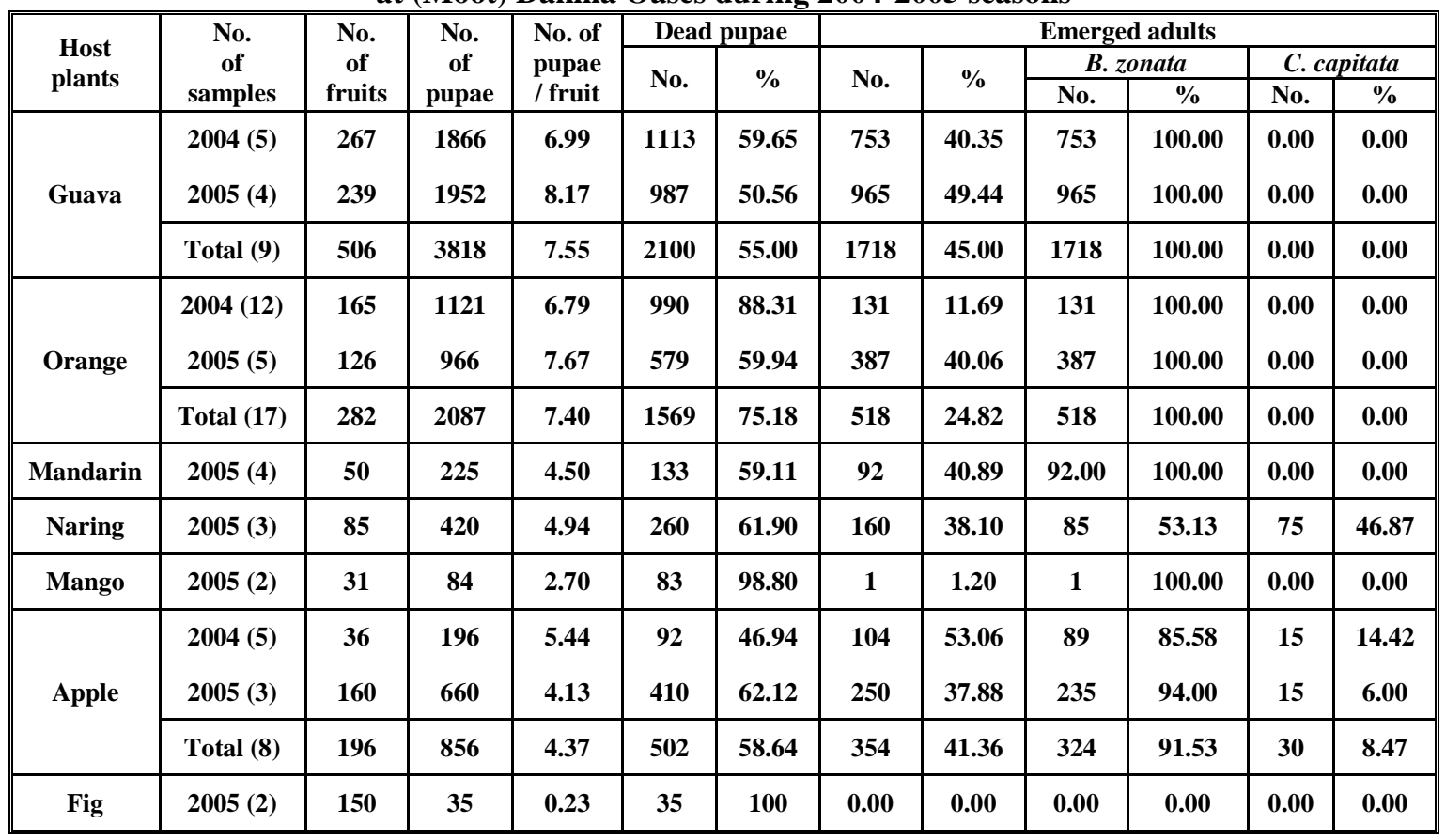


Table (3): Infestation predisposition of host plants to Bactrocera zontata and Ceratitis capitata at Bodkholo (Dakhla) Oases during 2004-2006 seasons

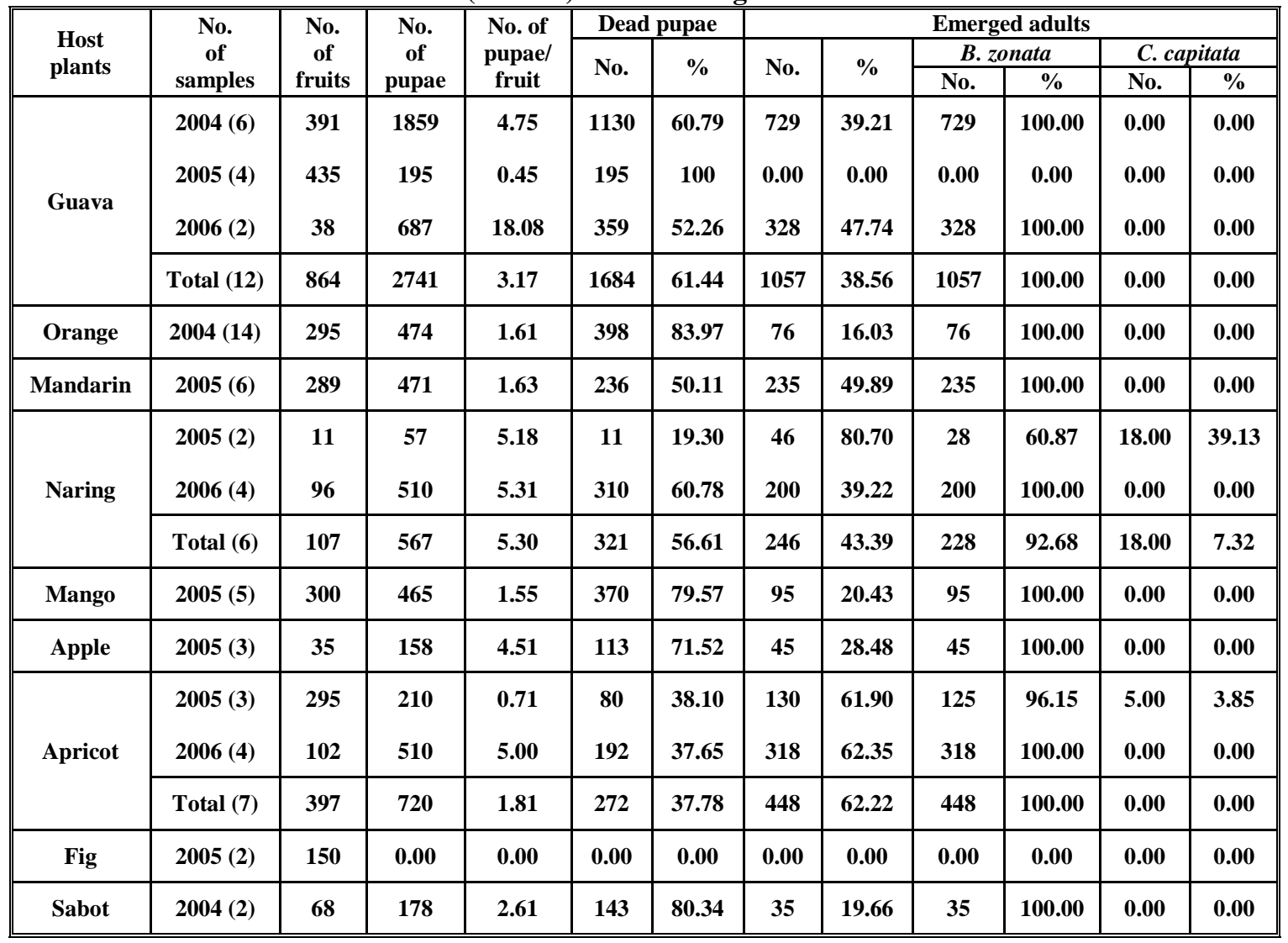

Data obtained from Bodkholo province (Table 3) were quite similar with those obtained from Moot province. With the exception of Apricot which recorded the highest percentage of the emerged adult flies (62.22\%). Mandarin, Naring and Guava took the second rank by 49.89, 43.39 and $38.56 \%$ and followed by Apple, Mango, Sabot and Orange by 28.48, 20.43, 19.66 and $16.03 \%$, respectively. Also, no adult flies were emerged from pupae collected from Fig fruits. In general, data showed that $B$. zonata ranked the first in respect to the number and the percentage of emerged adults than $C$. capitata. Fruit flies infestation patterns were studied on certain host plants e.g. Guava and Peach as reported by Vargas et al., (1983),
Harris and Lee (1986) and Mohammed (2003). In the New Valley Oases, the remaining of fruits on and under trees in the neglected mixed orchards provided a continuous source of flies. Environmental factors could be responsible for variations appeared on the infestation rates between the studied locations. Differences between the infestation predisposition measured by the number of pupae/fruit could be dependent on gabs in the suitability of fruiting trees, plant morphology and/or antixenosis phenomenon, while the real infestation measured by the percentage of the emerged adult flies/fruit could be dependent on the antibiosis phenomenon of the selected host plants. 


\section{Relative susceptibility of host plants to the fruit flies:}

Data presented in Table (4) summarizes the mean numbers of the emerged adult flies and the susceptibility degree of the tested host plants to $C$. capitata and $B$. zonata complex. Statistical analysis of the data revealed highly significant differences $\left(F^{* *}>0.01\right)$ between all of the tested host plants, the studied localities and their interactions. The used statistical method enabled to classify the tested host plants into various relative resistance categories. Because it harbored the highest mean numbers of emerged adult flies, Naring appeared as highly susceptible host plant (HS). It followed by Orange and Guava, which appeared as susceptible host plants (S). However, Mandarin and Apple showed some sort of resistance and appeared as relatively resistant (RR) host plants. The lowest numbers of emerged adult flies were recorded on Mango, which appeared as a moderately resistant (MR) host plant.
Because no adult flies emerged from pupae collected from Fig fruits as previously mentioned in Tables (2\&3) it could be considered as a resistant $(R)$ host plant. These variations between host plants could enable farmers to avoid the highly infestation of the tephritid flies appeared on the susceptible ones by using monoculture method and concerned with the horticulture operations. The aforementioned variations in host plant susceptibility to the fruit flies infestation may be due to the presence of antixenosis (nonpreference) and/or antibiosis phenomena as reported by Van Emden (1987). This author indicated that antixenotic plants can be avoided or less colonized by pests seeking for oviposition sites. Also, he described antibiosis as the position of some property by the plant which directly or indirectly affected the performance of the pest in terms of survival, growth, development rate, fecundity, etc.

Table (4): Relative susceptibility of selected host plants to the infestation by fruit flies at the New Valley Oases during 2004-2006 seasons

\begin{tabular}{|c|c|c|c|c|c|}
\hline \multirow{2}{*}{$\begin{array}{l}\text { Province } \\
\text { Plant } \\
\text { Plants }\end{array}$} & \multicolumn{3}{|c|}{ Mean number of emerged adults/fruit } & \multirow{2}{*}{$\begin{array}{c}\text { Grand } \\
\text { mean } \pm \text { SD }\end{array}$} & \multirow{2}{*}{$\begin{array}{c}\text { Susceptibility } \\
\text { degree }\end{array}$} \\
\hline & Kharga & Moot & Bodkholo & & \\
\hline Guava & $1.05 \mathrm{l}$ & $3.39 \mathrm{c}$ & $1.22 \mathrm{k}$ & $1.89 \pm 1.30 \mathrm{c}$ & $\mathbf{S}$ \\
\hline Orange & $3.64 b$ & $1.84 \mathrm{~g}$ & $0.26 p$ & $1.91 \pm 1.69 b$ & $\mathbf{S}$ \\
\hline Mandarin & $2.84 d$ & $1.84 \mathrm{~g}$ & $0.81 \mathrm{~m}$ & $1.83 \pm 1.43 d$ & $\mathbf{R R}$ \\
\hline Naring & $6.42 \mathrm{a}$ & $1.88 f$ & $2.30 \mathrm{e}$ & $3.53 \pm 2.50 \mathrm{a}$ & HS \\
\hline Mango & $1.78 \mathrm{i}$ & $\mathbf{0 . 0 3 q}$ & 0.320 & $0.71 \pm 0.93 f$ & MR \\
\hline Apple & $0.75 n$ & $1.80 \mathrm{~h}$ & $1.28 \mathrm{j}$ & $1.28 \pm 0.74 \mathrm{e}$ & $\mathbf{R R}$ \\
\hline Mean & 2.74A & 1.79B & $1.03 C$ & 1.85 & - \\
\hline
\end{tabular}

$F$ value $=* *$ highly significant between host plants, localities and their interactions.

Means followed by the same letter in each column and row are not significantly different at 0.05 level of probability by Duncan's multiple range test. 


\section{REFERENCES:}

Abdel-Galil, F.A. (2007): Final report for the project no PS-FAI-020-03 entitled "Study on biological means for controlling the Mediterranean fruit fly Ceratitis capitata (Wiedemann) in New Valley Governorate" and submitted by the Academy of Scientific Research and Technology, Cairo, Egypt, 73pp.

Amro, M.A. (1999): Ecobiological studies on certain arthropod pests infesting selected cowpea cultivars and control strategy in arid-ecosystems. Ph.D. Thesis, Fac. Agric., Assiut Univ. Egypt, 238pp.

Chiang, H.S. and N.S. Talekar. (1980): Identification of sources of resistance to the bean fly and two other Agromized flies in soybean and mungbean. J. Econ. Entomol., 73 (2): 197-199.

Eskafi, F.M, and M.E. Kolbe. (1990): Infestation patterns of commonly cultivated, edible fruit species by Ceratitis capitata and Anasterpha spp. (Diptera: Tephritidae) in Guatemala and their relationship to environment factors. Environ. Entomol., 19 (5): 1371-1380.

Harris, E.J. and C.Y.L. Lee. (1986): Seasonal and annual occurrence of Mediterranean fruit flies (Diptera: Tephritidae) in Makaha and Wainea Vallyes, Oahu, Hawaii. Environ. Entomol. 15: 507-512.

Mohammed, A.A.A. (2003):Studies on the peach fruit fly, Bactrocera zonata (Saunders) and its control in Fayoum governorate. M.Sc. Thesis, Fac. Agric., El-Fayoum, Cairo Univ.128 pp.
Nosser, M.A. (1996): Mechanism of resistance in bean and cowpea varieties to certain sucking insects infestation. M.Sc. Thesis, Fac. Agric., Cairo Univ.

Snedecor, G.W. and G.W. Cochran. (1971): Statistical methods. Ames, Iowa: Iowa State University Press.

Tsitsipis, G.A. (1992): Nutrition, requirements. pp. 103-119. In: Robinson A.S. and G. Hooper (Ed.). Fruit flies, their biology, natural enemies and control. Elsevier, Amsterdam, Netherlands.

Van Emden, H.F. (1987): Cultural Methods: the plant. In: Burn, A.J., T.H. Coaker and P.C. Jepson (Ed.) Integrated pest management. 27-67, Academic Press, London, New York.

Vargas, R.I.; E.J. Harris and T. Nishida. (1983): Distribution and seasonal occurrence of C. capitata (Wiedemann) (Diptera: Tephritidae) on the island of Kauai in Hawaiian Islands. Environ. Entomol., 12: 303-310.

Weems, H.V. Jr. (1981): Mediterranean fruit fly, Ceratitis capitata (Wiedemann) (Diptera: Tephritidae). Entomology Circular No. 230. Fla. Dept. Agric. and Consumer Serv., Division of Plant Industry.

White, I.M. and M.M. Elson-Harris. (1992): Fruit flies of economic significance, their identification and bionomics. Wallingford, UK; CAB International.

http://www.eppo.org/Quarantine/Bactrocera_zo nata/bactrocera.htm 
القابلية للإصابة و الحساسية النسبية لبعض محاصيل الفاكهة لذباب الفاكهة المستوطن و النازح إلى واحات الو ادي الجديد بمصر البدان

* *مح عبد الرحمن حمد عمرو**، فاروق عبدالقوى عبدالجليل

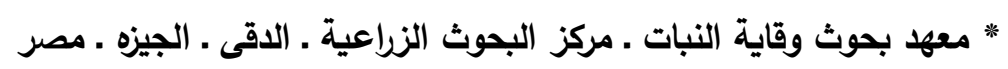

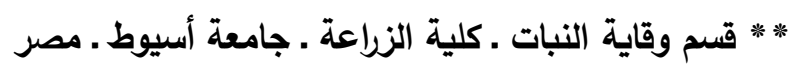

تناولت الدراسـة القابليـة للإصـابة والحساسية النسبية لبعض محاصيل الفاكهة المنزرعـة بالوادي الجديد لذبابة فاكهة البحرالأبيض المتوسط وذبابة الخوخ. وقد قدرت القابلية للإصابة بناءً على نسبة الحشرات الكاملة

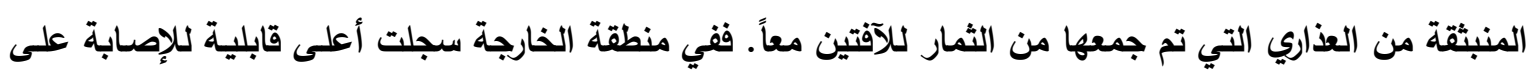

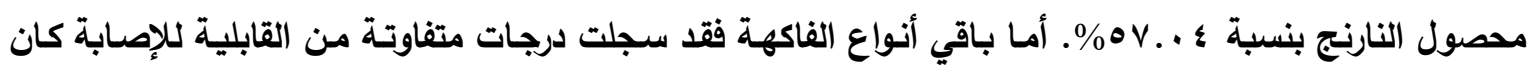

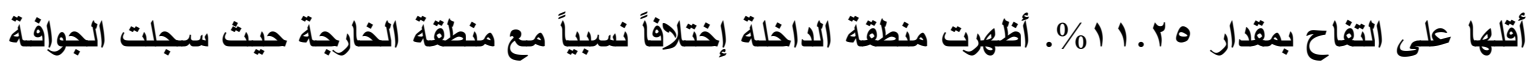

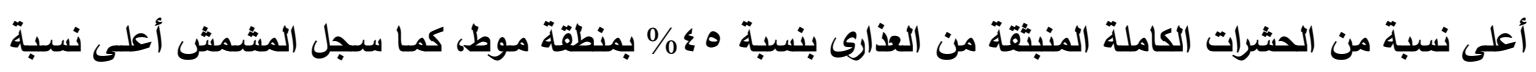

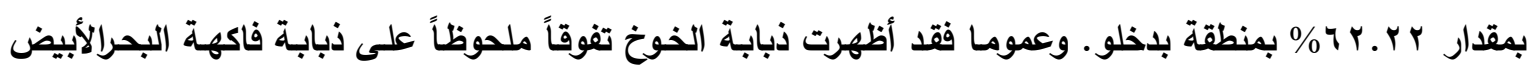
المتوسط فيما يخص عدد الأفراد الكاملة المنبثقة من العذاري والقابلية للإصابة. أوضح تصنيف العوائل النباتية المختبرة حسب درجة حساسيتها لذباب الفاكهة أن النارنج إحتل المركز الأول في الإصابة لمجموع اللآفتين معاً وبدا كعائل عالي الحساسية (HS). تـلاه بعد ذلك الجوافة والبرتقال وظهر كل

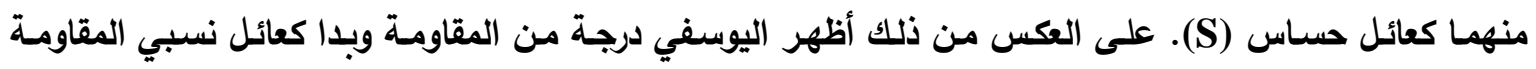

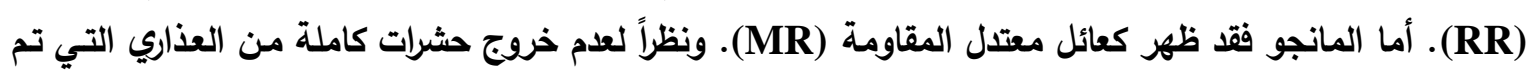

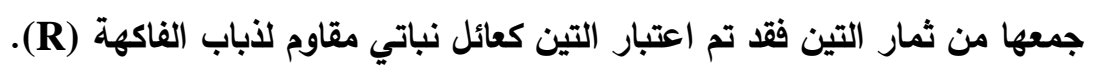

